\title{
Juridical Study of Crimes Committed with Computer
}

\author{
Soraya Rostami ${ }^{1}$ \\ 1 International Law PhD and Faculty Member in Payam Noor University of Alborz, Iran \\ Correspondence: Soraya Rostami, International Law PhD and Faculty Member in Payam Noor University of \\ Alborz, Iran. Tel: 912-366-6202. E-mail: Mpj.rostami@yahoo.com
}

Received: September 1, 2016

doi:10.5539/ass.v12n11p79

\author{
Accepted: October 4, 2016 \\ Online Published: October 14, 2016 \\ URL: http://dx.doi.org/10.5539/ass.v12n11p79
}

\begin{abstract}
By development of computer networks, computer -related crime spreading immoral that had negative impact on social systems including families and organizations and, more children were invaded by, the spread of computer crimes in the third world called cultural invasion.

Committing dishonest acts in ignorance or belief that the right to intervene in the operation of computer systems or data entry, or data deletion, or the messages. those committed acts does not categorize in fraud documentary, if the aforementioned act intended to endamage business rivals and if there is no property gained then that act does not categorize in fraud documentary too. Motivation and intention of act does not impact on kind of crime realization. E-commerce law states in Article 67: (perpetrator is punishable if committed as a result of using fraudulent means, personal or automated processing systems deceived in order to gain a person's property. For this reason, the mere intention to resort to dishonest means and education funds, property or privileges, is not sufficient to fulfill the offense.
\end{abstract}

Keywords: crime, computer, internet, network, legal materials, data, cyberspace

\section{Introduction}

The era of communication, an era in which human talents and technology progress considerably.an era of positive and negative manifestation of human creativity, an era when life in the virtual world of an idea and dream, has become an undeniable reality. Also within development there were always problems that had a negative impact and the entry of new products and different tools affect human society and human environment adversely. Investigation of different countries laws has revealed different understanding of criminal laws. There are lots of criminal acts in some societies that included non-criminal act in so many other nations today penal policy measures are influenced by the ideology and political views, customs, traditions and cultural characteristics of the nations (Note 1).

Law scientists each has defined crime in their point of views: for example, the School of absolute justice defined in this way: crime is any act contrary to morality and justice or Karofalou one of the founders of criminology stated crime as a violation of human moral sense the one that a certain part of moral sense include basic sensation of philanthropy honesty, rectitude and character of human being (Note 2).

Internet virtual world is one of the thousands of man-made that make it easy the difficulty access to information and data. today almost doing anything is impossible without Internet, because the Internet and computer services fill the gap of time and location among users and subscribers without internet thousands of users whose job involved with networks face lots of problems. Computers and networks connected to it according to experts opinions have different kinds. Crime in social point of view is the act that break social systems and this system in each era is proportional to civilization, thoughts and notions of that era. In this paper, those crimes has been studied that computers used as a means of commitment (Note 3).

Part I: Crimes against persons

In this section we are going to deal with crimes committed with computers that include crimes against persons, crimes against property, crimes against morality and decency, offenses against intellectual property rights violations and crimes committed by security and comfort that we will talk for each.

\section{Publishing and Dissemination of False News}

Dissemination of false news and false events in order to disturb public or official states opinions or to them are 
called dissemination of false (Note 4). In other words, the purpose of dissemination is that perpetrator disseminates news knowingly or deliberately against legal persons or official states that knows these news are false (Note 5).

Juridical reverence of vilification and false and dissemination of those are in undisputed sub alternate of rules of jurisprudence (Note 6). Within these jurisprudence rules, one can achieve to dissemination of false.

Dissemination of false from the attribution of false news to person or official's point of view looks like vilification act but the attribution of false in these crime is not crime.

\subsection{Crime Basics}

\subsection{Legal Elements of Traditional Dissemination of False}

Dissemination of false subject according to article 698 of Islamic penal code included the both evidence of criminal act that has been used in juridical verdict (Note 7). This crime has been written as a sub article of 269 with partially changed there.

In traditional criminal law, according to legal element of the crime. (Whoever with intention to harm others or disturbing public opinion, or the authorities or by a petition or complaint or report or correspondence or distribution of any printed matter or linear signed or unsigned falsehoods are saying, or the same acts contrary to the purpose to natural or legal person or official quoted implicitly or explicitly attribute, whether through the loss of material or spiritual in some way or other to be happened, or not, in addition to rehabilitation, if possible, to imprisonment from two months to two years or be sentenced to 74 strokes of the whip).

-3-Computer related Legal element of dissemination of false

Now in the law of computer crime, computer crime articles allocated 744 to 746 that is assigned to this material.

New articles of 744 Islamic penal code. (Anyone by means of computer systems or telecommunications has disseminate videos or audio with change or distortion of someone in a manner that would violate his /her reputation and dishonor him/her, has been sentenced to imprisonment of 91 days to two years or forfeiture of five to forty million or both of these verdicts according to the case).

Waver: If the perpetrator act in distortion or change were lurid and obscene, both of these verdicts will be sentenced to perpetrator.

Article 745 IPC (everyone with computer systems or by telecommunications means disseminate voice or image or a private video or family or other secrets without her/his consent except in cases of legitimate publish in a manner that result in the loss or defamation will be sentenced to imprisonment from one day to two years from five to forty million forfeiture or both of these verdicts).

Article 746 IPC (everyone with computer systems or by telecommunications means with harmful intention and purpose want to disturb public opinions to official states or to disseminate false or to access of others about them or with a same purpose quote those things with legal persons or others whether spiritual and material loss happened or not, in addition to rehabilitation, if possible to imprisonment from 91 days to 2 years or be sentenced to 5 million to million forfeiture in cash or both of them).

Legal elements of disseminating false crime included in 744 to 746 article.

\subsection{Material Element}

Material element of this crime is to disseminate false or ascribing these acts to legal persons, official states or others that has been written about these crimes in 744 to 746 article in computer related crimes. actually there has been two crimes said in these article one about dissemination of false and the other one is ascription of lies to official states, legal persons and the others.

So computer related dissemination of false and lies take place in computers systems and telecommunications and dissemination and spreading lies traditionally done by letter, complaint, epistle, petition, report or distributing any printed matter as quotes express or implied signature of the person natural or legal or official conversations take place

It is noteworthy that not only spreading and disseminating lies through the computer realized but really harmful than traditional one (Note 8).

\subsection{Spiritual Element}

General intent to commit the crime must know that it is through common PC or a statement Or to others, but the specific intent of this crime lies and unfounded and injurious to others and intend to public opinion or official 
authorities So if perpetrrator do not have the intention or prove the truth of this assignment is believed, will not be subject to judgment.

So knowingly committed the crime deliberately spreading lies and false statements requires inexistence or uncertainty principle prevents the realization of deliberateness of the act. The second component is intended to make the spiritual element of the crime. In other words, deliberation of commit act is another components of crime. The legislator has made exceptions on the top of the article.

Part II: crimes against property and ownership

In this section we want to explain about crimes against property or property in two most common types of fraud and theft.

\section{Computer Related Fraud}

Human worldwide today progress considerably in the field of computers and the rapid progress is going on each year and achieving new technology among these some greedy and jobber people took advantage of the situation to commit crimes using these device in another words doing computer related fraud

The first and most important recommendation of the recommendations put forward in the crime computer is computer related fraud (Note 9).

For more information about the description of computer fraud, commitement procedures and .... in this field will be explained (Note 10).

Fraud, is kind of crime against property and in the history of evolution and the evolution of computer systems become as one of the most important cases to come in the form of computer fraud. The crime offenders gain some properties through the application of false, altered, misuse of computer system and seize it (Note 11).

The main computer fraud is based on economic crime computer. Intangible assets in the form of objective (computer data), such as funds, deposits, or work hours, are the most common forms of computer fraud (Note 12).

In the modern business cash transfers and sales of commercial goods, fast way to transfer funds through the computer system. As a result, many facilities for the fraud acts and abuse will be provided (Note 13).

The kind of fraud is completely different with classic fraud, because the subject of computer fraud, in this fraud data represented as physical property of data processing systems

In most cases, computer fraud, actions that are representative of computer data, are immaterial Such as deposits, receivables, working time, the value of funds and balance sheet calculation results.

Fraud is mentioned as the crisis of the twentieth century (Note 14). The crime of fraud abstracted from theft crime and over time in our country has taken as an independent judicial system category (Note 15).

The most important characteristic that distinguishes fraud from other crimes is that lost property person, gives his/her property lost with the consent and sometimes vehemently to perpetrator, that commits him to gain significant benefit that perpetrator has promised Unaware of the behind the scenes of false promises and commit fraudulent, with the intention of getting the property from the scope of the seizure of property ownership (Note 16).

Over time, fraudulent instances has changed resulting in more losses as far as human societies most widely incur losses from this crime (Note 17). With the advancement of science and technology fraudulent do so and the achievements of these developments, to lure even more impeccable targets across the board (Note 18).

Fraud methods, the use of speaking in person or to draw colorful ads and distribute them among people or newspaper ad today have gone through the World Wide Web. However, up to this point there had been a breaking of the principles like traditional crime one, how to react with those crimes was not a problem in judicial law. The main element was the trick was in all of these instances there and just manner and means used how to lure people were different (Note 19).

But with the widespread use of computers, a type of attack on property and taking ownership of persons, the unauthorized and fraudulent acts when computers put into existence even the use of fraud expression in them was in doubt (Note 20).

For example, when someone manipulates information in a computer database system and transferred funds from another account into his/her account

And using cheque bank in order to get the money, this action called fraud or theft, is questionable. 
Because the fraudulent acts happened, but the owner was not lured and perhaps had not been seen by perpetrator also calling this act as steal of someone's property according to common law was impossible, in any case after so many discussions the expression of fraud is used in these kind of acts.

After removal of this uncertainty, it was observed that due to the lack of (deception) lost their property in this new type of fraud in the legal elements of fraud (traditional) law dealing with this new crime and therefore not attributable to countries in international instruments were recommended Title (computer fraud) to criminalize this act.

It is noted that with regard to the doctrine of the mean international instruments title (computer fraud) or (related computer fraud), (pure computer fraud) against (traditional computer fraud) because (Traditional computer fraud) was the same traditional fraud with new means through PC.

For example, using false propaganda on the Internet that are punishable by the same traditional rules Simply because it is different than other types of non-computer crimes and a series of practical considerations such as the need for such as acquisition rules, including electronic environment has been categorized in this way (Note 21).

\subsection{Definition of Computer Fraud}

Is the definition of a classic fraud different from computer fraud? To determine this, first we will define the classical fraud. Expression of fraudulent act or hat someone's hat off means cheating and luring and deceiving someone's concept and in order to seize someone's property.

The current law's definition of fraud and crime, just know it enough to mention some examples (Note 22). This is the first instance in the matter of punishment for perpetrators of bribery and embezzlement, fraud and confirmation of the Expediency Council, adopted on 28.06.1364 Parliament expressed Drmvrkhh 09/15/1367

Scam is defined as follows: Scam is defined as take someone's possessions by have bad intentions to equipment or fraudulent operations (Note 23).

It is also have another definition as: (Take another wealth by use of fraudulent tools or taking other one wealth by fraudulent ways) (Note 24).

It was understood that one the realization of crime conditions are scam, deception and victim. And to delude, that a crime against a person is conceivable.

However, according to this point is under this broad definition include the computer Tricks? Here we should separate this one into two cases: The first case is when that, person target the computer and from a computer (as a means fraudulently) do the mentioned cases as intensify the perpetrators of bribery and embezzlement and Scam. For example, via the computer introduced himself as business owners, that does not exist and through this way rubs people's wealth. Or introduced himself as some famous person, to people trust him, and give him their possessions. It seems that here also the definition included this case. The second case is when with no deceiving, tricky acts against computer systems is committed. In other words, the convict get enough money or a financial profit by the computer systems (Note 25).

In some law article, for penalties severe the act of bribery, embezzlement and fraud have been known as some instances of crime. In maximum punishment those who commuted in bribery, embezzlement and fraud known as some point of crime evidence. ( everyone who deceive people with non-existence and virtual factories, companies and instituted or encourage people to virtual hopes or scare people from non-reality events and other incidents or adopt unknown name, rube every one possession. Is a hustler. And moreover than return the wealth the owner, sentenced to prison for 1-7 years and forfeit pecuniary)

This question was asked is the car cheated or not? It seems that tricking the machine require creative mind. Also, mentioned definition could not cover all the cases of fraud.

In many countries, there is not a definition of computer fraud. But the definition of the Council of Europe is (computer fraud is insert, change, or suspend the elimination of data or computer programs, that will effect on the outcome of the process.

According to article 67 of the law of e-commerce, if someone wants to do computer fraud and start to implement it, but the crime does not happen but discovered will be punished. Starting to do computer fraudulent act is the minimum charge of article 67 (Note 26).

In an inevitable necessity, using computers and possibility of misusing of the digital age is a major crisis, so prompted the legislature to reverse legal response. 
If the fraudulent acquisition of property by fraud does not give up, but for the most part of his/her account, misuse or employs the machinery and the debtor made a fraudulent manner and against the consent of the beneficiary harvest to, The scams, fraudulent operations before property acquisition and other property is the ultimate cause and exclusive education, so that victims of fraud, fraudulent operations under the influence, his wealth to surrender the person is a crook. The absence of such conditions, the realization has been ruled out fraud and internet fraud crime only the law may not see their potential victims, but funds them to grab their property (Note 27). Computer fraud include: unauthorized manipulations and illegal actions that included following items:

A) Entering data and information, both true and false: When entering data and information that leading to the acquisition of property or money and the rating, the fraud crime act happened.

B) Unauthorized modification of computer data: If the computer fraudulent act is true and the modification, acquisition of property, cash benefits and financial services acquisition, the crime is achieved.

C) Elimination of computer and telecommunication data: This includes the dismantling and removal of data. If this elimination was in order to acquisition of property, then this act can be considered as a fraudulent act.

E) Interfering with computer system tasks: disruption of illegal and unauthorized computer system dysfunction and when the system is in acquisition direction of education, wealth or privilege Yamnft funds or financial services committed in terms of success or lack of success in finding Drbrdn rated property or school property or privilege, to commit computer fraud Tom and begin to constitute fraud (Note 28).

One of the Conventional and traditional methods that is used, the method (Trojan horse) in which computer instructions for computer programs secretly placed in the programs that do So that unauthorized operations Unlike regular operations and allow the application to run at the same time, this method that the capability to not leave any trace on the run. Examples of computer fraud: the abuse of the telephone network, the abuse of funds, abuse of plastic cards and more (Note 29).

Legal research magazine stated that (Note 30): (a key point in the definition of this crime is important, first, a material element of the crime in the context of electronic transactions and using information and communication technologies, such as applications and computer systems and equipment remote communication is done. Second, fraudulent actions that led to trick the automated processing systems, with examples such as logging, elimination and suppression performance data message or unauthorized intervention programs or computer systems or telecommunications equipment that related to information technology. Of course, like the traditional type of fraud, the material acts, must necessarily lead to achievement of results and injurious to others. In other words, the perpetrator must apply the act with organization to take another's property, otherwise fraud cannot be achieved).

Electronic fraud, like the traditional fraud, is deliberate and fraudulent acts in addition to the general intent, specific intent, non-winning property is also a condition of complete mental element. In other words, ignorance committed to fraudulent acts or the belief that the right to intervene, for example, the computer system performance or data entry, or wipe the data message, then acts committed categorized outside the scope of the fraud. Moreover, if the above acts done with intent to harm competitor arrivals in this way, no way, no property or financial is gained, this action does not constitute fraud. Like other offenses, motivation does not affect in crime, the mental element and the completion of the acts committed general intent, even if the motivation was to commit the acquisition of property for the benefit of the needy, the practice of the crime take place. Acquisition of, property or financial concessions belonging to other parties, whether in favor of the perpetrator or a third party, if it leads to the destruction of property, criminal fraud is traceable.

Electronic fraud, crime, destruction of property and other conditions, it is bound by the law of e-commerce in the context of Article 67 that is considered. The term used in article (... someone's property) confirms this picture that propetrator committed, if punishable as a result of using fraudulent means, personal or with decieving automated processing systems and thereby take someone's property. The mere intention to resort to dishonest means and education funds, property or privileges, is not sufficient to fulfill the crime committed fraudulent acts and should therefore, be sustained financial losses to individuals, even if the perpetrator of a criminal act and therefore not benefit and criminal profits to third parties is reached. In other words, if the realization of the crime, harm to others and use the perpetrator or a third party. This is in the context of Article 8 of the Convention offenses committed in cyberspace also taken into consideration and given financial loss to a third party fulfillment of the conditions that cause crime. 


\section{Conclusion}

The prevalence of cybercrimes, causing diversity damage in society. Destroying the moral and social order, damage and irreparable damage to the economy and computer fraud is one of the harmless in communities. The dissemination and spreading of computer crimes has mentioned cultural invasion in the Third World. Crimes committed with computer is divided into several categories, crimes against persons, crimes against property, crimes against intellectual property, offenses against public decency and morality and crimes against public safety. In this context lots of fraudulently act is used. Ignorance of someone at those acts has changed the act from fraudulent documentary. If the aforementioned act was with the intention of hurting the rival commercial and no property has gained, this act is not categorized in fraudulent operation, motivation and intention of the act has not impact on kind of crime. E-commerce law states in Article 67: (perpetrator is punishable if committed as a result of using fraudulent means, personal or automated processing systems deceived in order to gain a person's property. For this reason, the mere intention to resort to dishonest means and education funds, property or privileges, is not sufficient to fulfill the offense.so it will be better to prevent from fraudulent act with some ways. The most important way to deal with such offenses is to maintain the moral foundations of society by comprehensive fighting of society, as well as other methods, legal control transfer of data on computer networks at the international level and in the end is the destruction of active criminal groups in the communities.

\section{References}

Abadi, K., \& Samad, A. (2013). IT crimes. Law Magazine, p. 147.

Amelii, H., \& Hassan, M. Vasaelo shiie, 12, 210.

Ardabili, M. A. (2010). General criminal law (p. 119).

Bastanii, B. (2001). Computer Crime manifestation of new Delinquency (p. 41). Mizan Publication.

Bay, H. A. (2010). Legal and jurisprudential review of cybercrimes (p. 310). Mofid publication.

Javadii, S. H. (2003). Journal of Legal Discourse, 3, 45.

Javadii, S. H. (2013). Computer Crima. Journal of Legal Discourse, 128.

Javid Nia, J. (2015). Electronic commerce crime (p. 224). Sadra publication.

Langrodii, J. (2002). Terminology the rights (p. 714). Library of Gange danesh Publication.

Mir Mohammad Hossein, S. (2010). Crimes against possessions ownership (p. 51). Mizan Publication.

Pad, E. (2013). The provisions of the IPC (p. 322). Mizan publication.

Pakzad, B. (2013). International organizations and regional action about computer crime. Magazine of political rights, p. 120.

Shokri, R., \& Ghader, S. (2013). IPC in the current order (p. 811). Mizan Publication.

Tavanam, A. (2015). Criminology (p. 105). Sanjegh and Amozash publication.

Zadeh, H., \& Jafar, M. (2008). Specific criminal law (crimes against property) (p. 118). Samt Publication.

Zobeir, O. (2004). Computer Crimes (p. 20). Gange Danesh Publication.

\section{Notes}

Note 1. Tawana, Ali, Criminology, page 105.

Note 2. Ardabili, Mohammad Ali, General criminal law, page 119.

Note 3. Ardabili, Mohammad Ali, General criminal law, page 120.

Note 4. Shokri, Reza and Ghader, Siroos, IPC in the current order, page 811, Jaffarii Langrodii, Terminology the rights, page 714 .

Note 5. Validi, Mohammad Saleh, same, page 346.

Note 6. Horr Amelii, Mohammad Hassan, Vasaelo shiie, Volume 12.

Note 7. Bay, Hossein Ali and Por Ghahraman, Babak, Legal and jurisprudential review of cybercrimes, page 290.

Note 8. Bay, Hossein Ali and Por Ghahraman, Babak, Legal and jurisprudential review of cybercrimes, page 294. 
Note 9. Javadii, seyyed Hadii, Journal of Legal Discourse, number 3, page 45.

Note 10. Bay, Hossein Ali and Por Ghahraman, Babak, Legal and jurisprudential review of cybercrimes, page 303.

Note 11. Bastanii, Bromand, Computer Crime manifestation of new Delinquency, page 3.

Note 12. Zobeir, OLerish, Computer Crimes, page 20.

Note 13. Mir Mohammad Sadeghi, Hossein, Specific criminal law (2), page 38.

Note 14. Mir Mohammad Sadeghi, Hossein, Specific criminal law (2), page 38.

Note 15. Briefing Report,..., Electronic commerce law, page 51, Javid Nia, Javad, Electronic commerce crime, page 273 .

Note 16. Javid Nia, Javad, page 28.

Note 17. Mir Mohammad Sadeghi, Hossein, Specific criminal law (2), page 28.

Note 18. Javid Nia, Javad, Electronic commerce crime, page 224.

Note 19. Same 224.

Note 20. KHoram AbaDi, AbDol samad, IT crimes, Page 147.

Note 21. Same, Javid Nia, page225.

Note 22. Dehkhoda dictionary, under the word hat ...

Note 23. Mir Mohammad sadeghi, Hossein, Crimes against possessions ownership, Page 51.

Note 24. Habib Zadeh, Mohammad Jafar, specific criminal law (crimes against property), Page 118.

Note 25. Bay, Hossein Ali, Legal and jurisprudential review of cybercrimes, page 310.

Note 26. Farashanian, Farahnaz, Dissertation Page 73, goldozian, Erage, Necessary for criminal law, page 181.

Note 27. Farashanian, Farahnaz, Specific criminal law, Page 205.

Note 28. Goldozian, Erage, Necessary for criminal law, page 207.

Note 29. Bastanii, Bromand, Computer Crime manifestation of new Delinquency, page 41.

Note 30. Journal of Research Law and Politics, Number 25, pp. 129 to 132; goldozian, Erage, Necessary for criminal law, page 207.

\section{Copyrights}

Copyright for this article is retained by the author(s), with first publication rights granted to the journal.

This is an open-access article distributed under the terms and conditions of the Creative Commons Attribution license (http://creativecommons.org/licenses/by/4.0/). 